\title{
THE OPINIONS OF ROMANIAN EXPERTS ON BREXIT: CAUSES AND CONSEQUENCES
}

\author{
Mihnea Daniel NĂSTASE1
}

\begin{abstract}
After a number of postponements, Britain's ratification of the withdrawal agreement has finally initiated the transitional period, during which the negotiations between the United Kingdom and the European Union will be finalized. Brexit has and will continue to affect the structure and relationships between EU member states. With a history of positive perceptions towards the EU and its institutions, Romania continues to believe in the rhetoric launched by Brussels. However, the implications of Brexit with regards to Romania are plenty - commercial, economic, political and geostrategic. In order to understand how the United Kingdom's withdrawal from the European Union affects Romania, this paper attempts to thematically analyse a series of interviews with Romanian experts and elites. The interviews discuss the historical and political context of Brexit, and how Brexit affects Romania and Romanian citizens' attitudes towards the Union. Recent statistics show that more than 400.000 Romanians reside in the UK and as such, one of the core matters raised in this paper concerns the status of Romanians in the UK postBrexit.
\end{abstract}

Keywords: Brexit, Romania, Romanian Experts, Euroscepticism, European Union

In order to evaluate the perception on the subject of Brexit, its causes and effects on Romania and the attitudes of Romanian citizens towards the European Union, a thematic analysis was undertaken on a series of in-depth interviews with Romanian experts who have a leading role in their areas of activity and who can express a valid and well-informed point of view on the subject. This paper manages to bring together the perspectives of political elites, mass media, academics and sociologists, who are able to disseminate information, shape public opinion, and influence the political decisionmaking process in Romania. As a member state of the European Union and in the context of a potential contagion of the 'exit' phenomenon in Europe, analysing and understanding the attitudes of experts and elites that are able to forge either pro-EU or anti-EU discourses in Romania is of paramount importance for the future of both Romania and the European Union.

\footnotetext{
${ }^{1}$ National University of Political Studies and Public Administration, Bucharest, Romania; e-mail: mihnea.nastase@gmail.com
} 


\section{The Politics of Brexit}

As a former empire and colonial power, the United Kingdom has always approached the European Union and, more specifically the EU's enlargement process, from a distinct and uncommon standpoint. Opposition to the European project has been a cornerstone of British foreign policy, observable since the UK's accession to the European Economic Community in 1971. Attitudes towards the European Union have been directly assessed by British citizens following the attempt of British prime-minister David Cameron to gain electoral advantage. With rising nationalistic sentiments in the UK, the populist movement - methodically steered by the UK Independence Party succeeded in politically pressuring the Conservative Party and its leader to call for an EU membership referendum after the May 2015 general elections. The announcement fractured British society in supporters of 'leave' or 'remain' - forcing debates on various issues such as identity, sovereignty, economic costs versus benefits, and migration (Ashcroft, 2016; Harris, 2016; Riley-Smith, 2016). Further research has explored the entanglement of individual and regional motives (Abreu \& Öner, 2019; Adam \& Mertens, 2020) that have led to the United Kingdom's historic decision to withdraw from the European Union in what became widely known as the 2016 Brexit referendum.

The foundations of European integration, or disintegration, involve multiple spectrums, having socio-economic, socio-cultural, political, institutional and territorial facets (Eppler \& Scheller, 2013). The study of European disintegration (Vollaard, 2018) discusses the context-specific mechanism that interconnects macro-dynamics and micro-components with the EU decision-making machinery (Hedstrom \& Swedberg, 1998; Mason et al., 2013).

The European Union has reached a crossroads. Ruptures and divisions between the EU27 have resulted from zero-sum games that have caused difficulties in dealing with considerable crises that have had a direct impact on the lives of British citizens, such as the economic and financial crisis, an identity crisis and economic convergence crisis, the refugee crisis, a security threat crisis, near-exits by other member states, the expansion of the Russian sphere of influence into the Western Balkans, as well as an EU institutional and decision-making transparency crisis. As a new form of European disintegration, Brexit is characterized by the mainstreaming of Euroscepticism and antiEU sentiments (Brack, 2018). Following deadlocks in negotiations between the EU27 and the UK towards arriving at an agreement, the UK finally ratified its decision to withdraw from the EU on January 31st, 2020, allowing for the final stage of Brexit negotiations to be finished by the end of the transitional period.

\section{Romania and Brexit}

This paper attempts to analyse the perception of Romanian experts towards Brexit. As such, it is important to take note of the official position that Romanian authorities have had towards the United Kingdom's withdrawal and the negotiations ensuing from this decision. 
Former prime-minister Viorica Dăncilă has declared that, internally, Romania began preparing for Brexit starting with March 2017, when a cross-ministerial mechanism was created to oversee negotiations (Gov.ro, 2019). George Ciamba, former minister of European affairs, iterated that Romania would not suffer direct economic consequences post-Brexit, in terms of GDP, according to the current trade balance (Ministry of Foreign Affairs, 2019). However, Romanian authorities have encouraged the option of a 'soft' Brexit, with negotiations between the UK and the EU27 reaching a withdrawal agreement (Romania2019.eu, 2019; Presidency.ro, 2019). According to the permanent representative of Romania to the European Union, Luminita Odobescu, a 'hard' Brexit would severely affect Romania's most important objective, securing the rights and liberties of Romanians living in the UK post-Brexit (Petrescu, 2019).

Following the UK's withdrawal from the European Union, the president of Romania, Klaus Iohannis, reiterated that Romania's core objective during the Brexit negotiations has been maintaining the rights and freedoms of Romanians living in the UK and that this matter is properly reflected in the withdrawal agreement (Presidency.ro, 2020). The president also discussed the necessity to further Romania's strategic partnership with the UK and the need to establish a close relationship between the EU27 and the UK post-Brexit (Presidency.ro, 2020).

\section{Methodology}

Twelve Romanian experts and elites, both practitioners and theorists, from the economic, political, diplomatic, academic, sociological, and mass media spheres, have been chosen to participate in a series of interviews in order to convey opinions on the matter of Brexit that are well-balanced, diverse and representative. Rich et al.'s 18 point approach to conducting "elite interviews" (2018: 324-325) was utilized in order to construct the interactional framework with interviewees, while respecting the approaches of research interviews (Suchman \& Jordan, 1990; Abell and Myers, 2008), and addressing convergent and discriminant validity (Beamer, 2002). Although conducting 'elite interviews', this paper attempts not to overuse the term "elite" and has preferred to refer to respondents generally as experts. Many academics have had problems with agreeing on a general definition for elites (Harvey, 2011). As such, when referring to experts and elites further in this paper, these are defined as individuals that have key positions in their social frameworks, with extensive knowledge in their fields of activity and who are able to exert influence (Parry, 1998; Smith, 2006). The decision to limit the sample size was taken upon reaching the saturation of information on the subject.

As a measure of anonymity for the interviewees, which have not, however, disclosed classified information, only a general title and initials will be made public throughout this paper. The participating interviewee from the field of economy is F.G., a member on the board of the National Bank of Romania. The political elites interviewed are two former members of the European Parliament from the 2014-2019 legislature, A.C. and E.P.; L.O., permanent representative of Romania to the European Union; former minister of European affairs G.C., who had an active role in Brexit negotiations and in the first Romanian Presidency of the Council of the European Union; and S.T., former 
ambassador of Romania to the Kingdom of Belgium, currently a director in the Romanian ministry of foreign affairs. With regards to candidates from the academic field of activity, two professors F.A. and M.P. - political scientist and sociologist were chosen as respondents. Another sociologist, M.K., was asked to offer a perspective on Brexit and its impact on Romania. The media personalities interviewed were a journalist and talk show producer, A.U.; a journalist that reports on European affairs, S.I.; and B.C., a journalist and political analyst.

The interviews were conducted between May 5th and July 20th 2019. The research interviews were semi-structured, with an 'elite/expert' interview approach, and had a duration that ranged from 14 to 56 minutes. Literature suggests that interviews carried face-to-face are more efficient and often offer more information than telephone interviews (Sturges \& Hanrahan, 2004). Thus, it was decided to utilize a face-to-face scenario to conduct the interviews. A recording device was used in the interviews in order to provide a verbatim transcript, while being able to effectively follow-up on questions and important aspects (Richards, 1996) - maximizing the allocated interview time. The transcripts have been thematically analysed, with data being categorized into four different topics of interest for a more methodical and in-depth analysis, while maintaining a holistic approach with distinct arguments that lead to understanding Romania's position and perspective in the context of Brexit.

The following list of questions was used as a guide to conduct the interviews:

Q1. What are the core issues that have caused the UK's decision to withdraw from the European Union?

Q2. Could you describe the most important actors and vectors that triggered the electoral decision for Brexit?

Q3. What are the problems that Romania will face as an effect of Brexit?

Q4. Will Brexit have economic and commercial consequences for Romania?

Q5. When negotiating with the UK, what key objectives should Romania focus on?

Q6. Will the status of Romanian workers in the UK be affected by Brexit?

Q7. Will Brexit cause a shift in the attitudes of Romanian citizens towards the European Union?

\section{Analysis and Interpretation of Results}

\section{Opinions of Romanian experts concerning the causes of Brexit}

Brexit must be analysed as a complex phenomenon with causes that stem from historical, political, cultural and geostrategic perspectives. In this context, the Romanian interviewed experts discuss the elements that have influenced British voters' opinions and triggered one of the most significant events in the history of the European Union. 
Romanian experts largely believe that Brexit primarily had socio-economic roots. The guarantee for the free movement of labor through the European Single Market led to a popular perception in the UK that "immigrants" - who were in fact citizens of the European Union - had been relocating extensively to the United Kingdom, and as a result had occupied jobs at a smaller wage, thereby creating unemployment for British citizens.

F.G. has an interesting point on the matter of socio-economic issues in the UK:

Socio-economic issues [caused Brexit], more precisely that [issue] of employment, the problem regarding the UK's structure of production that has shifted from the segment of relatively high complexity manufacturing to the area of preponderantly financial services. (F.G., Member on the board of the National Bank of Romania)

The dynamic of the UK economy has changed from its industrial and manufacturing origins to one based on financial institutions - concentrated in 'hubs' such as the City of London or Liverpool (professor and sociologist, M.P.). This adjustment created significant economic discrepancies for the lower and middle classes, making citizens believe that the costs of membership to the European Union had started outweighing the benefits (journalist and talk show producer, A.U.). This argument is also reinforced by former minister of European affairs (G.C.):

Brexit marks the beginning of a political phenomenon of anti-globalization. [...] Brexit was won in the cities that had smaller incomes per capita and that were affected deeply by deindustrialization. Brexit was not popular in London or wealthier zones. It has clearly also marked a line of British social division. (Former minister of European affairs, G.C.)

A matter that was openly agreed upon by interviewees was that of national identity and sovereignty as causes for Brexit. On one hand, this matter touches upon Britain's historical context, as a former empire and colonial power (former members of the European Parliament, A.C. \& E.P.). Citizens assumed that the freedom of movement in the EU was causing its society to neglect its own culture and traditions. On the other hand, citizens from the UK believed that their country was not as present in the decision-making process at the level of EU institutions as it should have been, with France and Germany having more leverage (member on the board of the National Bank of Romania, F.G.). An example that has been used multiple times to illustrate this point, mostly by experts that resided abroad, in Brussels, is that of how the EU's budget is established - also referring to the UKIP's backtracked slogan: "Let's give our NHS the f,350 million the EU takes every week" (McCann \& Morgan, 2016).

Several experts have also named political agents and decision-making as causes of Brexit. Although actors and vectors will be discussed in a subsequent chapter, a professor and political scientist (F.A.) offers an interesting view regarding the political context that led to the referendum on June 23, 2016:

The process started as a follow-up of a political miscalculation by prime-minister Cameron. [...] The unpopularity of the government, the fact that the UK's 
government had a very weak communication, led to co-actions in the context of a campaign based on lies, on falsehoods, the result of which, from a game, a political calculation, political marketing, has had important geopolitical consequences. (Professor and political scientist, F.A.)

The European Union has been used by the political elite in the UK as a convenient scapegoat for the lack of internal implementation of policies. Interviewees believed that the lack of efficient communication by the UK's government was speculated by the Eurosceptic, populist political movement in the UK. A journalist and political analyst (B.C.) refers to data mining, data analysis, digital profiling and targeting services that aided in this effort:

[...] a commercial society that influenced the vote, such as Cambridge Analytica.

[...] Well, perhaps the difference of four percent was influenced by Cambridge

Analytica. (Journalist and political analyst, B.C.)

A former ambassador of Romania to the Kingdom of Belgium (S.T.) has a very interesting approach towards the causes of Brexit, having a three point explanation from a macro to micro perspective. Firstly, the respondent discusses the UK's historical conduit, post-World War II, towards Europe and the coalitions that led to its accession in the 1970's - where the UK primarily aimed at achieving commercial advantages, while only secondarily aiming for direct economic incentives. Secondly, in the interviewee's opinion, the UK assumed that in the future, the European Union would become more political and less commercial as a construct. Finally, as a third point, S.T. referred to specific elements that relate to internal politics and the reality present in today's British society.

Professor and sociologist, M.P. concluded that the core reasons the UK has withdrawn from the EU are geographic and historical:

It had to do with a red line that generally characterizes a people throughout centuries of national attitudes and national pride, of identity and legitimacy. They did legitimate themselves through this matter, that 'we are different than the Europeans', this is what encapsulates the situation. (Professor and sociologist, M.P.)

All in all, the topic concerning the causes of Brexit is seen by Romanian experts as multi-faceted. Interviewees discussed at length socio-economic factors - also caused by globalization and deindustrialization - and the lack of efficient communication by authorities, all while discussing identity and sovereignty as causes that have historically spanned across centuries.

\section{The UK's withdrawal from the EU: vectors and important actors}

When discussing the actors and vectors that led to Brexit, the interviewed Romanian experts discuss both broad themes such as globalization and common values, as well as specific political actors and media. This theme brings together both internal, national factors, but also external players that have had an interest in creating divisions within the European Union through the UK's withdrawal. 
"Anti-globalization" is a factor that constantly emerges from interviews. Although this is a theme that has been mentioned earlier, in the previous chapter, in this case globalization is mentioned in the context of discontent citizens that are rejecting a model of globalization because the economic "trickle-down" could not be implemented down to the last worker (member in the board of the National Bank of Romania, F.G.). Interviewees talk about the problems of globalization internalized by UK citizens who became the primary actors in and of themselves with regards to the referendum on Brexit.

Here we talk about Brexit, [where people] felt excluded by perspectives of globalization. Thus, there was an association between the EU, globalization and poverty, and practically this is the central conclusion that created the switch for amassing the majority for the Brexit vote - representing traditional voters of the Labour party. (Former ambassador of Romania to the Kingdom of Belgium, S.T.)

Professor and political scientist, F.A. brings about an interesting point of view regarding the common values of UK citizens with citizens from former colonies as opposed to common values with other citizens from the European Union:

From a cultural standpoint, Englishmen feel closer culturally to Indians, than to Poles and Romanians for example, because they were part of an empire, and they connect more with imperial history than with the membership to the European Union. (Professor and political scientist, F.A.)

A factor that has been generally expressed through the interviews regards the internal political actors in the UK, more precisely Cameron and the Conservative Party. Respondent consensus exists with regards to the fact that the facilitator of the referendum was David Cameron, the prime-minister who called and organized the referendum.

He [David Cameron] was the one that dotted the "i" and crossed the " $\mathrm{t}$ ", $[\ldots]$ he kept his word and organized this referendum for the withdrawal of the United Kingdom from the European Union. (Former member of the European Parliament, A.C.)

On one hand it was the decision of the Government from the time to organize this referendum and call a discussion concerning the role of UK in the EU, while on the other hand [the actors responsible for Brexit] are those who campaigned against, for "leave". (Permanent Representative of Romania to the European Union, L.O.)

The Conservative Party and its leader were surely an actor, who - as I said before tried to resolve a political and electoral issue by triggering a game, with the thought that he will manage to emerge victorious from it. (Professor and political scientist, F.A.)

Besides the significant role that prime-minister Cameron and the Conservative Party played in the organization of the referendum, another party has also been central to the implementation of Brexit, namely the UK Independence Party (UKIP). The populist movement was able to use misleading and deceptive slogans and disseminated false information in order to bring traction to the "leave" campaign. UKIP, according to 
interviewees, was at the forefront of the battle for the UK to sever its ties with the European Union.

The flag-bearers [for the Brexit vote] have always been Farage and the UKIP movement. (Former member of the European Parliament, E.P.)

Without a doubt [another significant factor] were the Eurosceptics -by definition, those in the Independence Party, UKIP and its leader, Nigel Farage, with their campaign that was full of lies - also being supported by the North American conservative Right. (Professor and political scientist, F.A.)

The support received from North America, discussed in the previous quote, refers to a company that proved essential in data mining, profiling and targeting British citizens with precise information that would persuade the voter in favor of the "leave" option.

I believe the practical reason behind the UK's withdrawal from the European Union is based on the game designed by Cambridge Analytica, the British commercial company that managed to utilize social-media and target messages depending on the client they had. They had Nigel Farage as client for Brexit, just as they had Donald Trump, in the United States, and so they had two historical successes. (Journalist and political analyst, B.C.)

Romanian experts did not assume that only 'new media' influenced the final Brexit vote. Rather, that many owners of traditional media outlets also supported the "leave" campaign (permanent Representative of Romania to the European Union, L.O.), choosing to represent a series of threats that ultimately were proved false, such as the expected "invasion" of the UK by Bulgarians and Romanians (Journalist and talk show producer, A.U.).

The interviews also concerned external vectors that had an impact on Brexit. According to a few of the interviewees, international players would much prefer dealing with a weakened and divided European Union:

I am convinced that countries such as the Russian Federation had a direct interest in seeing a Brexit occur. (Former member of the European Parliament, A.C.)

Let us not forget that even the United States are discretely interested in a weaker European Union, in order to undermine the economic power of the Common European formula. It is a win just as significant for the protagonists of the greater, international game from Asia, while Russia has, without a doubt, an interest for the European Union to not be cohesive and efficient. As such, each individually, through their connections and means, at separate moments, contributed to what already existed within the borders of the United Kingdom, to the amplification of a sentiment that it would be much better to have a British flag without stars around it. (Journalist and talk show producer, A.U.)

All in all, Romanian experts presented a perception that Brexit, as an event, was influenced by both internal and external actors. Internally, political figures were clearly identified - both as parties and as individuals - while traditional and social media vectors were discussed more generally. In terms of external factors, a few major players 
64 The opinions of Romanian experts on Brexit: causes and consequences

on the international stage were framed as having direct interests in Brexit occurring not as a direct implication for the United Kingdom, but rather for the European Union.

\section{Negotiating the UK's withdrawal: how Brexit affects Romania and its citizens}

In the discussions regarding the UK's withdrawal negotiations, as well as how they will affect Romania, specialists addressed various topics that concern Romanian citizens residing in the UK, as well as commerce and the economy. Furthermore, respondents discussed at large how Romanian authorities managed the Brexit negotiations.

A central subject for interviewees, regarding Brexit negotiations, regarded the rights of citizens living abroad in the UK. A serious concern was voiced by former members of the European Parliament (A.C. \& E.P.), who based on internal debates and information, disclosed that the EU27 and the European institutions were adamant against the policy of "cherry picking" work force that the UK attempted initially. Moreover, with a firm stance, both stated that if the UK wanted to remain in the Common Market, it needed to respect the fundamental conditions regarding the freedom of goods, services, capital, while emphasizing labour (A.C. \& E.P.).

Member on the board of the National Bank of Romania, F.G. offered an explanation for the reason such a numerous work force from Romania decided to live abroad:

We are the ones that accounted for the socio-economic costs of integrating in the European Union, of globalization, by closing down the more inefficient production facilities and hence reducing the employment opportunities for the work force, which created waves of migration towards the more developed countries in the West, including England (member on the board of the National Bank of Romania, F.G)

The most important subject in this theme revolved around the Romanian work force and students in the United Kingdom. Interviewees raised points on this matter even before being specifically asked about the labour market. It is uncertain if this topic has developed so significantly due to the media or because of its political significance. The permanent representative of Romania to the EU (L.O.) explains that the community in the UK is extremely important and that it is an extremely important political subject for Romania. All of the respondents agreed that the most important objective for Romania in the Brexit negotiations is that of maintaining the rights and liberties of those citizens that have been already integrated in the British society post-Brexit.

In terms of the balance of trade, commerce and economy, experts do not voice as much concern as they do regarding the labour force.

In the financial world, England is not a massive presence on the Romanian market. Not [an important presence] in the banking sector, while on the capital market only some entities are present, but not very significant. Thus, the important objective is that of the labour market. It is important [for Brexit] not to affect the status of workers that are activating there. (Member on the board of the National Bank of Romania, F.G.) 
For Romania, it is not an extraordinary propagation since the trade balance is quite modest with the UK. There are countries outside of the European Union, such as Turkey, with whom we have a trade balance that is five times larger. Even more so when looking at Germany. On the other hand, a certain cycle can exist for some of the affected states that have a large trade balance with the UK, such as Germany or the Netherlands. These, in turn, are principal commercial partners for Romania. Thus, a zone of contagion can occur. (Former minister of European affairs, G.C.)

Interviewed experts also discuss the matter of EU cohesion funds in the Brexit context. The UK, as the second largest net contributor to the budget of the European Union is withdrawing, while Romania remains the second largest beneficiary of cohesion funds. With the UK leaving, France and Germany become the largest contributors and they may seek to redirect funds from the EU budget to matters that affect them directly, such as Northern Africa, the Middle East, the migration crisis and security (former member of the European Parliament, A.C.).

When referring to how Romania has dealt with Brexit negotiations, opinions diverge. On one hand, interviewees believe that Romania failed to obtain as much as it could from the negotiations and that what was achieved regarding the rights and liberties of Romanian workers in the $\mathrm{UK}$ is a result of all EU member states having the same interest, with the UK expecting reciprocity from the EU27. The majority of the Romanian experts believed that Brexit negotiations are only truly held between France, Germany and the UK - and that Romania only validates these negotiations as part of the EU27.

Unfortunately we are not able to capitalize on what could have been benefits for Romania. There are many first moment advantages that we were not able to capitalize on, from the relocation of companies, to the resettlement of institutions in Romania - we can remember, for example, our application for the European Medicine Agency - to filling out positions in the administrative structure of the Council, the European Commission, positions vacated by the English public workers. [...] Our only win was that of a single place of a member of the European Parliament, that we obtained with some anxiety through the redistribution of places in the Parliament from Brussels as a result of British MPs leaving. (Journalist and talk show producer, A.U.)

Romania does not negotiate, Romania only votes for the decisions of the important powers, it is naive [to believe otherwise]. [...] The big powers negotiate, Germany, France, while we, the small member states - except Poland and Hungary that have a different trajectory, vote depending on their decisions. (Professor and sociologist, M.P.)

Realistically, negotiations only take place according to France and Germany, with regards to the United Kingdom (Professor and political scientist, F.A.)

An interviewed expert has an even more discouraged opinion concerning Romanian diplomacy overall, not just when discussing Brexit: 
66 The opinions of Romanian experts on Brexit: causes and consequences

Realistically, Romania does not have a good relationship with anyone at this moment. It does not have channels of dialogue. It does not have a powerful diplomacy. It does not have an informal diplomacy. At this moment in time, Romania has failed. Thank God that we are within the European borders and not outside. However, Romania, from a political and diplomatic standpoint, is a failed state. (Journalist and political analyst, B.C.)

On the other hand, as expected, those that were actively involved in the act of government or in the Brexit negotiations directly have a different opinion, explaining that the most important objectives that Romania had in these negotiations have been met.

The Brexit negotiation, in the end our objectives were achieved. Our central objective was maintaining the rights of European citizens, and through the accord negotiated by Barnier, this matter has been respected. (Former minister of European affairs, G.C.)

From our point of view, at this time, we consider that the initial objectives assigned by Romania have been reflected very well in the withdrawal agreement. (Permanent representative of Romania to the European Union, L.O.)

The only perspective that discussed the possibility of a hard Brexit and what it would mean for Romanian citizens is that of professor and political scientist, F.A. Although perhaps not the most popular opinion, F.A. discusses that a hard Brexit, without an agreement, would be an advantage and opportunity for Romania since some of the citizens from the UK would be forced to relocate to Romania:

If a hard Brexit would occur, it could prove an advantage on the medium term, since some of the population would return to Romania. Action which could fuel the country's economic dynamic. (Professor and political scientist, F.A.)

All in all, interviewed experts have found three important points where Brexit negotiations affect Romania: the rights and freedoms of Romanian citizens in the UK, commercial and economic effects, and the maximization of benefits from negotiations. It appears the most important objective, that of Romanians in the UK, has been successfully negotiated - perhaps, according to experts, because of a common interest by the EU27 and the desire for reciprocity by the UK. Economically speaking, Brexit will not have a direct impact on the Romanian economy. Indirectly, however, a domino effect could cause pressure on trade balances with Germany or the Netherlands, which in turn could affect the Romanian economy. Finally, there was an interesting contradiction among respondent opinions when discussing the negotiations. Those involved in the negotiations were content with the outcome, while others felt a cost of opportunity and that not enough was done by the Romanian side in bilateral discussions with the UK, in the attempt to relocate companies post-Brexit and when negotiating with the European institutions. 


\section{Brexit and the attitudes of Romanian citizens towards the European Union}

When discussing the influence of Brexit on the attitudes of Romanian citizens towards the EU, the interviewed experts generally refer to the reasons why Romanians are very unlikely to become Eurosceptic - starting from historical matters and ranging to pragmatic and cost versus benefit analyses. When prodded further regarding attitudes towards the European Union, numerous reasons for the possibility of accentuated Euroscepticism are brought up, focusing predominantly on internal factors.

All interviewees agree on the fact that Brexit, as an event, will not stimulate negative attitudes for Romanians towards the European Union.

I do not believe [that Brexit] will diminish the optimism of Romanians towards the Union because Romania has always seen in the EU, with regards to politicoeconomic matters, in NATO, concerning military of national security issues, model clubs which one needs to join in order to modernize and develop. As such, when England, which is a great economic power, decided to develop outside of the club, it was its own option. [Brexit] takes places because its [the UK's] status as a 'big', developed country with huge economic potential gives it this option. We, as a competitor, a smaller runner, cannot perform in a globalized world without rules. We cannot swim or navigate on an ocean of globalization with our small boat, Romania. (Member on the board of the National Bank of Romania, F.G.)

I do not think that there is someone in Romania who would blame the European Union [for Brexit], it would make no sense, since it was not the European Union that decided for the UK to leave, but the UK that chose to withdraw from the European Union. (Former minister of European affairs, G.C.)

Even if Brexit does not impact perceptions strongly in a direct manner, the outcome of negotiations between the European institutions, the EU's member states and the United Kingdom could have a significant consequence in terms of perception. Former member of the European Parliament (E.P.) brings this issue up:

I do not believe that the UK's withdrawal from the EU has an influence on the perception of Romanians towards the European Union. However, the moment that the result of the negotiations will not be a desired outcome [by citizens], then things could change. If we, as the EU27 are not able to protect the rights of our citizens in the UK, then yes, I believe that the EU will lose face and its image will be affected not only in Romania, but also in all other 27 states. (Former member of the European Parliament, E.P.)

Attitudes against the European Union are not a desired political outcome in Romania. Sociologist M.K. explains that Romania is perhaps the only country in the European Union that does not have a political movement, a party with a Eurosceptic manifesto. Furthermore, the central political parties and media trusts in Romania have not launched campaigns against the European Union at all (Professor and political scientist, F.A.). 
Although Romanians have a positive attitude towards the European Union, and according to the interviewed experts they will continue to be Euro-enthusiasts, the channels of information from the EU or its institutions are not direct to the Romanian citizens. Rather, Romanian elites act as a catalyst for stimulating European debates and for disseminating the appropriate information. Interviewees have mentioned that "elites explain" (member on the board of the National Bank of Romania, F.G.), and that "national authorities are the transmission belt" (journalist reporting on European Affairs, S.I.) for information, events and decisions that are taken at the EU level. This point is perhaps best encompassed in a comment made by former ambassador of Romania to the Kingdom of Belgium (S.T.):

For us [Romanians], Brussels is abstract, people cannot know what decisions are taken there. The message is still spread by means of the internal elites, not directly from Brussels. (Former ambassador of Romania to the Kingdom of Belgium, S.T.)

Another point that has been discussed extensively refers to a correlation between proEU attitudes and economic benefits for Romanian citizens. Romanian experts believe that euro-enthusiastic or eurosceptic attitudes have a direct correlation with a cost versus benefit analysis that is internalized in the Romanian collective perception.

A part of the Eurosceptic movement, which is fortunately still weak and I believe it will remain weak for a long time, has not gained momentum due to the non-existent conviction that we are not benefiting as a result of our membership to the European common family. (Journalist and talk show producer, A.U.)

As long as Romanians can find well-paid employment in the European Union, their sentiments towards the European Union will remain positive. (Professor and sociologist, M.P.)

There is another view however, saying that joining the EU has not had a major economic impact for those living in the country. S.I. explains that:

Romanians have felt the freedom of movement much stronger than citizens from other member states. The fact that one can work abroad was another benefit that Romanians could feel. [...] Perhaps these are the economic benefits, the fact that they [Romanians] were able to work abroad for better wages. It was not necessarily economic benefits in their own country, because unfortunately the matter regarding the absorption of European funds could not be experienced so strongly by the citizens in order to relate economic benefits directly to a pro-European attitude. (Journalist reporting on European Affairs, S.I.)

With a diaspora amounting to more than four million citizens, and tens of thousands of individuals in all of the better performing economies of the EU (journalist and political analyst, B.C.), indeed it seems that in order for economic benefits to be internalized collectively, they do not need to even be implemented in Romania. Clearly, out of the four freedoms guaranteed by the European Single Market, the freedom of labour is by far the most essential for Romanians.

Respondents followed-up with a series of issues that could lead to Euroscepticism, after asserting that Brexit would not play a part in such a shift. In this case the danger of 
fueling negative attitudes towards the EU lies with Romanian authorities primarily, but also with regards to a certain perceived double standard in the EU's decision-making processes.

There are decisions that have an impact on citizens' or our [Romanians'] attitudes towards, not necessarily the European Union in and of itself, but rather regarding the way in which certain decisions are taken - an example being the impact caused by our non-accession to the Schengen Area. (Permanent Representative of Romania to the European Union, L.O.)

Romania is profoundly integrated in the European Union, but not at the top, where, unfortunately, the current political sphere [in Romania] is not able to communicate with the European political elite. Matters are fundamentally different from the period of Adrian Năstase, when the European elite would dialogue with the Năstase government. Now, only the base of the pyramid communicates with the European Union. (Journalist and political analyst, B.C.)

If elements pertaining to European skepticism appear in Romania, they are not caused by this [Brexit]. They [Eurosceptic attitudes] can be generated by other matters, from the phenomenon of discrimination, from differences in terms of treatment, which is why social cohesion is just as important as economic cohesion and why maintaining the fundamental freedoms of the European Union, as they are, is crucial for us. It is not possible to choose the freedom of goods or services against the freedom of movement for citizens or the freedom of labour. (Former minister of European affairs, G.C.)

A possible explanation regarding the current positive attitudes towards the EU, come from how Romanians' perceive their own identity. This is a matter that has been discussed in previous chapters, specifically when referring to it as a cause for Brexit itself. When discussing about the Romanian identity however, certain experts think that Romanians are drawn much more to their European identity than their Romanian identity. (Professor and sociologist, M.P.) M.K. goes even further in describing this phenomenon:

The Romanian discards his national identity with ease when departing to work in Italy, Spain or the United Kingdom. (Sociologist, M.K.)

All in all, the Romanian experts interviewed have fallen in agreement over the fact that Brexit, as an event, will not affect the attitudes of Romanian citizens towards the European Union. A strong case is made regarding the benefits - mostly economic - for citizens as a result of Romania's membership to the European Union. In the opinions of the interviewees, the benefits heavily outweigh the costs. However, even if Brexit is not likely to have an impact on Romanian attitudes, there are other factors that could cause Euroscepticism. On one hand these are internal, that are specific to the political elites and authorities, while on the other hand they are external - relating to certain decisions, based on double standards or discrimination, taken at the EU level regarding Romania. 


\section{Conclusions}

The interviews conducted with the twelve representatives from the political elite, the economic sector, academic sector and mass media offer a broad view concerning the causes and effects of Brexit as a phenomenon. A thematic analysis was used in order to categorize and efficiently structure the information collected in the interviews into four chapters, offering a holistic perception from Romania regarding the causes of Brexit, the consequences of Brexit for the EU and how Brexit will affect Romania and its citizens.

Brexit is an anti-globalization phenomenon, validated by the resentment of individuals affected by deindustrialization. This sentiment does not find its roots in civil society, but rather it is present even today through a Trump-Johnson duo that, having an isolationist approach, promote a new formula of globalization with rules and regulations.

The central causes of Brexit are socio-economic and historical in nature, oddly being the same elements that construct the pro-European narrative in Romania. A conclusion can be drawn, thus, that the cost-versus-benefit analysis of the membership to the EU weighs heavily on the perception of the EU that collective attitudes in a country have towards other member states. The larger economies in the EU managed to thrive on the continuous enlargement of the European community, through the guarantees of European Single Market - the free movement of goods, services and capital in the European Union. However, it is the free movement of labour - the freedom most valued by Romanian citizens - that created the necessary rhetoric that UKIP used to spearhead their „leave” campaign - wanting a Europe „a la carte”, attempting to cherry pick both the desired labour force and the policies and freedoms that allowed the UK to capitalize massively in the newly constructed zero-sum structure of the European Union (A.C.).

In terms of the negotiation of Brexit, Romania has managed to secure its most important objective, the rights and liberties of the over 400.000 Romanian citizens that are residing in the United Kingdom. Although further steps could have been taken in order to secure additional advantages, the Romanian authorities preferred to rely on the direction received from France and Germany, the EU27 and the European institutions. Romanian experts saw Brexit as a regional, isolated event, which will not affect the attitudes of Romanian citizens towards the European Union. With Romanian elites still acting as catalysts and disseminators of messages and information from the European Union, Romanians perceive Brussels and the EU as an abstract entity (S.T.). This matter is also central to this paper, as the interviewed experts and elites that activate in various fields of activity are those who internalise the information and discourses that stem from Brussels and propagate their analyses towards the Romanian public sphere. As such, according to experts, Eurosceptic attitudes in Romania could only be caused by "fake news" circulated by experts and mass media, by Romanian authorities inefficiently implementing European policies, or by double standards present in the decision-making mechanism at the EU level. 
With an insecure common foreign policy, economic zero-sum games present at the core of the Union, and many other crises that create divisions between member states, the European Union finds itself at a crossroads and must find a future direction that involves the common interests of the whole EU27, so that smaller, less integrated member states can continue obtaining economic, internal or external, benefits in order for attitudes to remain Euro-enthusiastic and prevent additional exits from occurring.

\section{References}

Abell, J., \& Myers, G. (2008). Analyzing Research Interviews. In: Wodak, R., Krzyżanowski, M. (Eds.): Qualitative Discourse Analysis in the Social Sciences (pp. 145-161). Macmillan International Higher Education.

Abreu, M., \& Öner, Ö. (2019). Disentangling the Brexit Vote: The Role of Economic, Social, and Cultural Contexts in Explaining the UK's EU Referendum Vote. (October 10, 2019). Available at SSRN: https://ssrn.com/abstract=3327181 or http://dx.doi.org/ $10.2139 /$ ssrn. 3327181

Adam, R. G., \& Mertens, G. (2020). Brexit: causes and consequences. Cham, Switzerland: Springer.

Ashcroft, M. (2016). "How the United Kingdom voted on Thursday... and why". Retrieved from http://lordashcroftpolls.com/2016/06/how-the-united-kingdom-voted-and-why.

Beamer, G. (2002). Elite Interviews and State Politics Research. State Politics \& Policy Quarterly, 2(1), 86-96.

Brack, N. (2018). Euroscepticism in the European Parliament. In Brack, N. (Ed.): Opposing Europe in the European Parliament: Rebels and Radicals in the Chamber (pp. 51-81). Palgrave Macmillan, London.

Eppler, A., \& Scheller, H. (2013). Zur Konzeptionalisierung europäischer Desintegration: Zug-und Gegenkräfte im europäischen Integrationsprozess. Nomos Verlagsgesellschaft.

Gov.ro (2019, October 2) Retrieved from https://www.gov.ro/ro/media/comunicate/primireade-catre-prim-ministrul-viorica-dancila-a-negociatorului-ef-al-uniunii-europene-privindbrexit-michel-barnier

Harris, J. (2016). "If you've got money, you vote in ... if you haven't got money, you vote out". The Guardian. Retrieved from http://www.theguardian.com/politics/com mentisfree/2016/jun/24/ divided-britain-brexit-money-class-inequality-westminster.

Harvey, W. S. (2011). Strategies for conducting elite interviews. Qualitative Research, 11(4), 431-441.

Hedstrom, P., \& Swedberg, R. (1998). Social mechanisms. Cambridge University Press: Cambridge.

Kaili, E., Psarrakis, D., van Hoinaru, R. (2019). New Models of Financing and Financial Reporting for European SMEs. Cham, Palgrave Macmillan.

Mason, K., Easton, G., \& Lenney, P. (2013). Causal social mechanisms; from the what to the why. Industrial Marketing Management, 42(3), 347-355.

McCann, K., \& Morgan, T. (2016, June 24). "Nigel Farage 350 million pledge to fund the nhs was 'a mistake". The Telegraph. Retrieved from https://www.telegraph.co.uk/news/2016/ 06/24/nigel-farage-350-million-pledge-to-fund-the-nhs-was-a-mistake/

Ministry of Foreign Affairs (2019, March 5). Retrieved from https://www.mae.ro/node/48231 https://www.mae.ro/node/48231

Ministry of Economy. Retrieved from http://www.imm.gov.ro/ro/brexit-implicatiile-scenariuluino-deal/ 
72 The opinions of Romanian experts on Brexit: causes and consequences

NBC News (2018). "Angela Merkel Calls For Creation Of A True European Army". Retrieved from https://www.youtube.com/watch?v=7gHOA2y9BzU

Parry, B. (1998). Hunting the gene-hunters: the role of hybrid networks, status, and chance in conceptualising and accessing 'corporate elites'. Environment and Planning A, (30), 2147-2162.

Petrescu A. (2019, August 29). Interviu Luminita Odobescu, ambasadorul Romaniei la UE: Riscul unui Brexit fara accord e foarte mare. Ne preocupa situatia cetatenilor romani. Mediafax. Retrieved from https://www.mediafax.ro/politic/interviu-luminita-odobescu-ambasadorul-romaniei-la-ue-riscul-unui-brexit-fara-acord-e-foarte-mare-ne-preocupa-situatiacetatenilor-romani-18335279

Presidency.ro (2019, October 18) Retrieved from https://www.presidency.ro/ro/media/declaratii-de-presa/declaratii-de-presa-sustinute-depresedintele-romaniei-domnul-klaus-iohannis-inaintea-participarii-la-reuniunea-consiliuluieuropean1571388631

Presidency.ro (2020, January 31) Retrieved from https://www.presidency.ro/ro/media/comunicate-de-presa/declaratie-de-presa-apresedintelui-romaniei-domnul-klaus-iohannis-cu-privire-la-retragerea-regatului-unit-almarii-britanii-din-uniunea-europeana

Rich, R. C., Brians, C. L., Manheim, J. B., \& Willnat, L. (2018). Empirical Political Analysis: Quantitative and Qualitative Research Methods. Routledge.

Richards, D. (1996). Elite Interviewing: Approaches and Pitfalls. Politics, 16(3), 199-204.

Riley-Smith, B. (2016, June 20). Leave or Remain in the EU? The arguments for and against Brexit. The Telegraph. Retrieved from http://www.telegraph.co.uk/news/2016/06/ 16/leave-or-remain-in-the-eu-the-arguments-for-and-against-brexit/

Romania2019.eu (2019, March 15) Retrieved from https://www.romania2019.eu/2019/03/15/prime-minister-viorica-dancila-met-with-theeus-chief-negotiator-for-brexit-michel-barnier/

Smith, K.E. (2006). Problematising power relations in 'elite' interviews'. Geoforum, (37), 643-653.

Sturges, J.E. and Hanrahan, K.J. (2004). Comparing Telephone and Face-to-Face Qualitative Interviewing: A Research Note. Qualitative Research, 4(1), 107-118.

Suchman, L., \& Jordan, B. (1990). Interactional Troubles in Face-to-Face Survey Interviews: Rejoinder. Journal of the American Statistical Association, 85(409), 232-241.

Vollaard, H. (2018). European disintegration: A search for explanations. Palgrave Macmillan UK. 